\title{
Ontogenetic development of the sagittal otolith of the anchovy, Anchoa tricolor, in a subtropical estuary
}

\author{
Barbara Maichak de Carvalho ${ }^{1}$, André Martins Vaz-dos-Santos ${ }^{2}$, Henry Louis Spach ${ }^{3}$, \\ Alejandra Vanina Volpedo ${ }^{4}$ \\ ${ }^{1}$ Programa de Pós Graduação em Zoologia, Departamento de Zoologia - UFPR, Centro Politécnico, Caixa Postal 19.020, \\ CEP 81.531-980, Bairro Jardim das Américas, Curitiba, Paraná, Brazil. E-mail: bmaicarvalho@ gmail.com \\ ${ }^{2}$ UFPR, Departamento de Biodiversidade, Laboratório de Esclerocronologia. Rua Pioneiro, 2153, CEP 85950-000, Palotina \\ PR, Brazil / Programa de Pós Graduação em Aquicultura e Desenvolvimento Sustentável - UFPR / Programa de Pós \\ Graduação em Aquicultura e Pesca, Instituto de Pesca (SAA-SP). \\ ${ }^{3}$ Programa de Pós Graduação de Sistema Costeiro e Oceânicos, UFPR, Av. Beira-Mar, s/n, CEP 83255-976, caixa postal \\ 61, Bal. Pontal do Sul, Pontal do Paraná, PR, Brazil. \\ ${ }^{4}$ Instituto de Investigaciones en Producción Animal (INPA-CONICET), Centro de Estudios Transdisciplinarios del Agua \\ (CETA-Universidad de Buenos Aires), Av. Chorroarin 280, Buenos Aires 1427, Argentina.
}

\begin{abstract}
Summary: In order to characterize the ontogeny of Anchoa tricolor, the morphology and morphometry of sagitta otoliths were described. A total of 397 pairs of sagitta otoliths of A. tricolor ( 20 to $85 \mathrm{~mm}$ ) were measured and analysed by means of digital images. Morphological description was done in terms of shape and features. The Huxley model was fitted to otolith length against total length (TL) and weight (TW), and residual analyses were done in order to detect the polyphasic growth. Six shape indices were calculated (otolith height/otolith length and otolith length/total length aspect ratios, rectangularity, roundness, relative sulcus surface and rostrum index) and after size effect removal, they were analysed in terms of TL. The results of these analyses allowed three distinct growth phases to be identified: (1) up to $40 \mathrm{~mm}$ TL and related to low swimming ability; (2) between 41 and 60-70 mm TL, when fish displacements increase but the first maturation has not yet occurred; and (3) after $71 \mathrm{~mm}$ TL, when fish become adults. Landmarks and semi-landmarks were used to analyse relative warps during the otolith development. The MANOVA analysis between the centroid size and class intervals showed significant differences in the interaction of all classes except between 71-80 and 81-90 $\mathrm{mm}$.
\end{abstract}

Keywords: shape index; geometric; morphometry; Engraulidae; Brazil; description.

Desarrollo ontogénico del otolito sagitta de la anchoa, Anchoa tricolor, en un estuario subtropical

Resumen: Se describen la morfología y morfometría de los otolitos sagitta de Anchoa tricolor con el objetivo de caracterizar su ontogenia. Se midieron un total de 397 pares de otolitos sagitta de A. tricolor (20 a $85 \mathrm{~mm}$ ) y se analizaron por medio de imágenes digitales. La descripción morfológica se hizo en términos de forma y características. Se ajustó el modelo de Huxley a la relación longitud del otolito, longitud total (TL) y peso (TW), respectivamente, y se realizaron análisis de residuos para detectar el crecimiento polifásico. Se calcularon seis índices de forma (OH/OL y OL/LT radios de aspecto, rectangularidad, redondez, superficie relativa del sulcus e índice de rostrum) y, una vez eliminado el efecto de talla, se analizaron en términos de longitud total. Los resultados de estos análisis permitieron identificar tres fases distintas de crecimiento: (1) una fase inicial, hasta $40 \mathrm{~mm}$ TL y relacionada con una habilidad natatoria baja; (2) entre 41 y 60-70 mm TL, cuando los desplazamientos del pez aumentan, pero aún no se ha producido la primera madurez y (3) superior a $71 \mathrm{~mm} \mathrm{TL}$, cuando el pez es ya adulto. Se utilizaron puntos homólogos y puntos equidistantes para analizar deformaciones relativas durante el desarrollo del otolito. El análisis MANOVA entre el tamaño del centroide y los intervalos de clases de talla mostraron diferencias significativas en la interacción de todas las clases, excepto entre 71-80 y $81-90 \mathrm{~mm}$.

Palabras clave: índice de forma; geometría; morfometría; Engraulidae; Brasil; descripción.

Citation/Como citar este artículo: Carvalho B.M., Vaz-dos-Santos A.M., Spach H.L., Volpedo A.V. 2015. Ontogenetic development of the sagittal otolith of the anchovy, Anchoa tricolor, in a subtropical estuary. Sci. Mar. 79(4): 409-418. doi: http://dx.doi.org/10.3989/scimar.04218.31A

Editor: I. Palomera.

Received: January 29, 2015. Accepted: September 18, 2015. Published: November 3, 2015.

Copyright: (0) 2015 CSIC. This is an open-access article distributed under the Creative Commons Attribution-Non Commercial Lisence (by-nc) Spain 3.0. 


\section{INTRODUCTION}

The otoliths of teleosts are complex polycarbonate structures composed mainly of aragonite. Three pairs (sagittae, asteriscus and lapilli) are present in the inner ear chambers. They are responsible for equilibrium and audition (Popper et al. 2005). The otolith shape make them an important tool for taxonomical purposes (Nolf 1985, Volpedo and Echeverría 1999, Tombari et al. 2005), population identification (Campana and Casselman 1993, Carvalho and Castello 2013), ecology (Waessle et al. 2003, Avigliano et al. 2014), biology (Lombarte 1992, Vignon 2012, Avigliano and Volpedo 2013), life history (Campana 2001, Elsdon et al. 2008) and growth studies (Bellido et al. 2000).

Many qualitative attributes have been used to describe otolith morphology (Smale et al. 1995, Volpedo and Echeverría 1999, Assis 2005, Tuset et al. 2008), although morphometry reduces the subjectivity of this kind of analysis. The use of bivariate morphometry to describe the relationships between fish and otolith measurements is common (Cadrin and Friedland 1999, Ponton 2006, Perin and Vaz-dos-Santos 2014), including shape indices (Tuset et al. 2003a, Leguá et al. 2013). The association of traditional morphometry and geometric studies makes it possible to expand the use of otoliths as key elements for understanding species and populations (Rohlf and Marcus 1993, Monteiro et al. 2005, Vignon 2012).

Several studies have described morphological variations during the ontogenetic development of otoliths. Volpedo and Echeverría (1999) and Waessle et al. (2003) identified a strong modification in the otolith morphology of Micropogonias furnieri during the growth of individuals, associated with sexual maturation. Gonzalez-Naya et al. (2012) described a change in the type and otolith tail position of sagitta in Australoheros facetus associated with variations in habitat use. Vignon (2012) demonstrated the environmental influence on the morphology of the sagitta otolith during growth in Lutjanus kasmirai. De La Cruz-Agüero et al. (2012) showed variations in morphology and morphometry of otoliths of six species of the family Gerreidae. Carvalho and Corrêa (2014) identified a depression in the dorsal region of the sagitta otolith of Atherinella brasiliensis after its first maturity. These examples confirm the broad applicability of otolith morphology and morphometry.

The anchovy, Anchoa tricolor (Spix and Agassiz, $1829)$, is an important small-sized species (>110 mm) that forms shoals in coastal regions, bays and estuaries in the southwestern Atlantic (Whitehead et al. 1988). Classified as a euryhaline species (Araújo et al. 2008, Vilar et al. 2011), it grows up to $118 \mathrm{~mm}$ long, with a life span of 2.3 years (Whitehead et al. 1988). It has an isometric growth pattern (Vaz-dos-Santos and RossiWongtschowski 2013, Franco et al. 2013) and spawns between September and February (Araújo et al. 2008). Very few studies on the relationship between the species and estuaries are extant: the exclusive presence of juveniles and young fish of the year have been reported in Sepetiba Bay and in the Paranaguá Estuarine Complex (PEC), Brazil, with the occurrence of adults in open beaches outside these ecosystems (Araújo et al. 2008, Contente et al. 2011).

In the PEC, an important subtropical estuary of the southwestern Atlantic (Lana et al. 2001), anchovy coexists with six other congeneric species (Whitehead et al. 1988). It occupies a key position in the food web (Araújo et al. 2008), constituting an important prey for marine mammals, seabirds and other fish (Santos et al. 2002, Bugoni and Vooren 2004, Bornatowski et al. 2014). Some of these piscivorous species are top predators in the southwestern Atlantic and have different levels of conservation risk (IUCN 2014). Despite its importance, little is known about the life cycle of $A$.

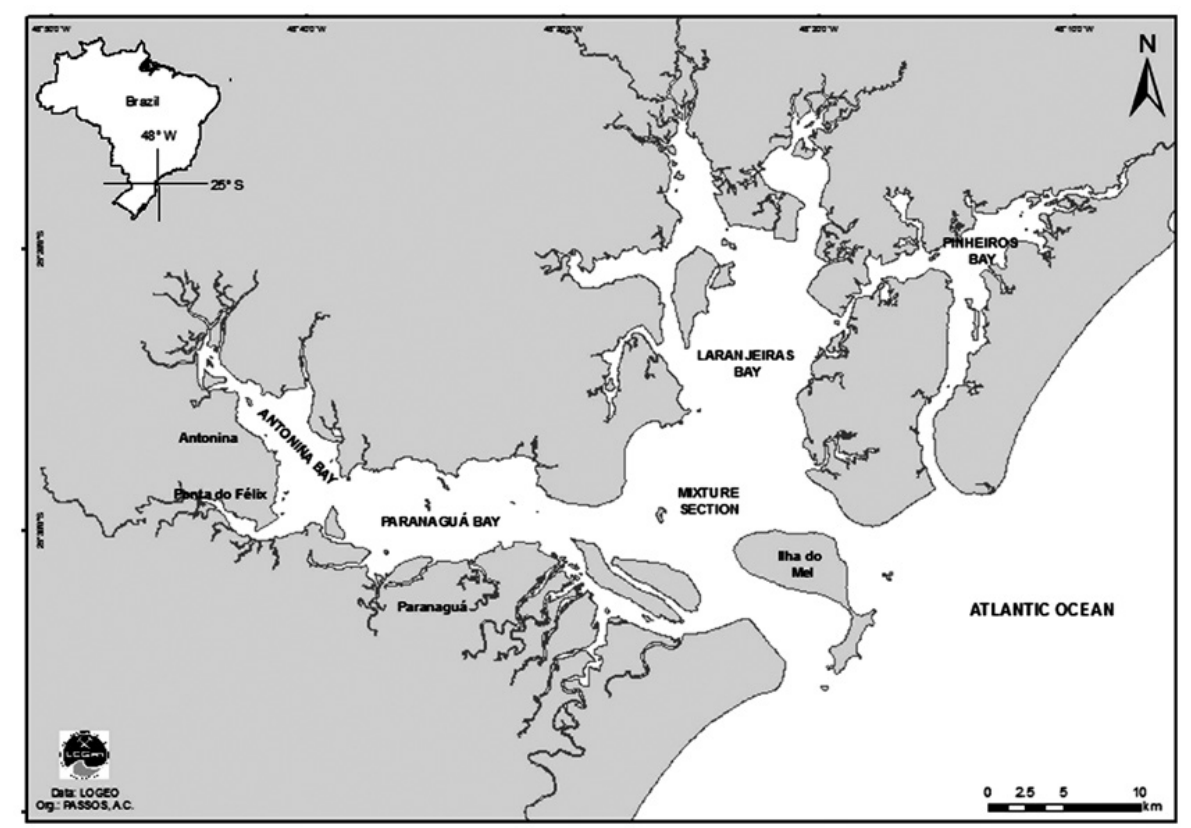

Fig. 1. - Map of the Paranaguá Estuarine Complex (Paraná State, Brazil). Source: Passos et al. (2012). 

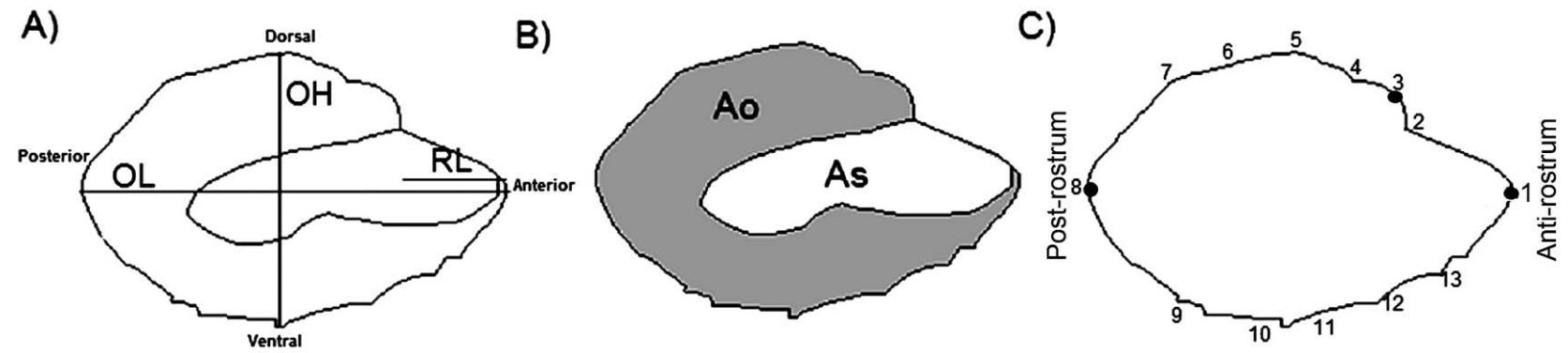

Fig. 2. - Morphometry of the sagittal otolith Anchoa tricolor from the Paranaguá Estuarine Complex (Paraná state, Brazil). A, longitudinal length of the otolith (OL), the greatest perpendicular height of the otolith $(\mathrm{OH})$ and the length of the rostrum (RL); B, area of the otolith (Ao) and area of the sulcus acusticus (As); C, position of the landmarks $(1,3,8)$ and semi-landmarks $(2,4,5,6,7,9,10,11,12,13)$.

tricolor and its contribution to the ecological compartments of the estuary, due to its misidentification. In this study, the morphological features and the morphometry of sagitta otoliths during the ontogenetic development of anchovy from the PEC are described, providing a useful and precise tool for its identification. Additionally, these results are also discussed in relationship to the life cycle of anchovy and may facilitate future studies of its stock.

\section{MATERIALS AND METHODS}

Monthly samplings were conducted between October 2010 and June 2011, consisting of trawls in the

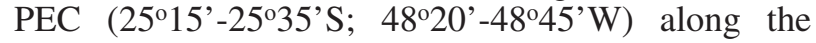
north-south axis (Fig. 1). Trawlers of $30 \mathrm{~m}$ were employed parallel to the coast at an average depth of 1.5 $\mathrm{m}$ using a beach seine net (length, $15 \mathrm{~m}$; height, $2 \mathrm{~m}$; mesh, $2.5 \mathrm{~mm}$ ) pulled by two people. In the laboratory, individuals of $A$. tricolor were measured for total length (TL in $\mathrm{mm}$ ) and weighed (TW in $\mathrm{g}$ ), and sagitta otoliths were extracted, cleaned and stored.

Only left otoliths from fish between 20 and $85 \mathrm{~mm}$ TL were selected for the analysis. The morphological features of the sagittae were described according to Tuset et al. (2008). For morphometric analysis, micrographs of otoliths of fish smaller than $30 \mathrm{~mm}$ TL were processed using a scanning electron microscope for a better resolution. Otoliths of fish larger than $30 \mathrm{~mm}$ TL were photographed using an Olympus DP71 coupled to a stereomicroscope. Otolith images were measured with the Image Tool 3.0 software (Wilcox et al. 2002). Data of otolith length (OL, maximum longitudinal length, $\mathrm{mm})$, otolith height $(\mathrm{OH}$, maximum perpendicular length, $\mathrm{mm}$ ), rostrum length (RL, the horizontal distance between the rostrum and the antirostrum, $\mathrm{mm}$ ) and the areas of the otolith $\left(\mathrm{A}, \mathrm{mm}^{2}\right)$ and of the sulcus acusticus $\left(\mathrm{mm}^{2}\right)$ were obtained (Fig. 2).

Three different analyses were used to characterize otolith morphometry of $A$. tricolor: regression analysis (Casselman 1990, Huxley 1993), shape indices (Tuset et al. 2003a, b, Volpedo and Echeverría 2003) and morphometric geometric analysis (Rohlf and Marcus 1993, Zelditch et al. 2004).

The Huxley model $\left(\mathrm{y}=a \mathrm{x}^{b}\right)$ was fitted between the TL and the total weight (TW) of fish and the OL (Huxley 1993). Data were previously transformed (ln) and the models were estimated by the linear least-squares method (Zar 2010). In order to detect changes in the growth pattern, analysis were performed following Bervian et al. (2006). The predictive variable (OL in size class of $0.1 \mathrm{~mm}$ ) was plotted against the average $\mathrm{x}$ values (TL and TW, respectively). The exponential coefficient of each size class $\left(b_{s c}\right)$ was estimated with the inverse Huxley model. Outliers $\left(-1.96<\mathrm{Z}_{\text {residual }}\right.$ $<+1.96)$ were removed. Then, the $b_{s c}$ values were plotted against the average $\mathrm{x}$ values and polynomial models were fitted. The first-order derivatives were used to estimate $b_{s c}$, allowing the detection of the stanza changing points of TL and TW, by solving the equations. The stanza changing points of TW were converted into TL through the inversion of the formulae $\mathrm{TW}=1 \times 10^{-6} \mathrm{TL}^{3.3623}\left(\mathrm{r}^{2}=0.9908, \mathrm{p}<0.001\right)$.

Six shape indices were calculated to describe otolith variation over ontogenetic development of anchovy: aspect ratios (OL/TL, OH/OL), rectangularity $[\mathrm{Rc}=\mathrm{A} /(\mathrm{OL} \times \mathrm{OH})]$, roundness $\left[\mathrm{Ro}=(4 \mathrm{~A}) /\left(\pi \times \mathrm{OL}^{2}\right)\right]$, relative sulcus surface $[\mathrm{Rss}=\mathrm{SA} / \mathrm{A}]$ and rostrum index $(\mathrm{Ri}=\mathrm{RL} / \mathrm{OL})$. Average values of each index were calculated by TL, minimizing the effect of different quantities of data (Bervian et al. 2006). The Huxley model was fitted to TL and each index by the linear least-squares method, with the outliers being disregarded (Zar 2010). The size effect of all individual data was removed by applying the formula proposed by Lombarte and Lleonart (1993) in which a corrected predictive variable ( $\left.\mathrm{y}^{\prime}\right)$ is estimated from the equation $\mathrm{y}^{\prime}=\mathrm{y}_{\mathrm{i}} \times\left(\mathrm{x}_{0} / \mathrm{x}_{\mathrm{i}}\right)^{b}$, where $\mathrm{y}_{\mathrm{i}}$ is the original value (shape index $), x_{0}$ is the referential value $\left(\mathrm{TL}_{\text {minimun }}=22 \mathrm{~mm}\right)$ and $\mathrm{x}_{\mathrm{i}}$ is the original TL value. With the corrected values, interval plots (means and their confidence intervals) were used to visualize ontogenetic variations of each shape index in relation to TL class (Tuset et al. 2003b, Volpedo and Echeverría 2003). After verification of assumptions, a permutational multivariate analysis of variance (PERMANOVA) with 9999 permutations using raw data (ln-transformed) and the similarity matrix (Bray-Curtis index) was used to ascertain differences between all shape indices and TL class (Anderson et al. 2008), followed by a post-hoc Mann-Whitney test with the Bonferroni correction (Zar 2010).

In order to characterize the geometric morphometry of A. tricolor, 274 sagitta of fish between 30 and $90 \mathrm{~mm}$ TL were analysed. Landmarks were positioned on structures with biological references in all class intervals, namely landmarks 1, 3 and 8, which represented the rostrum, the 


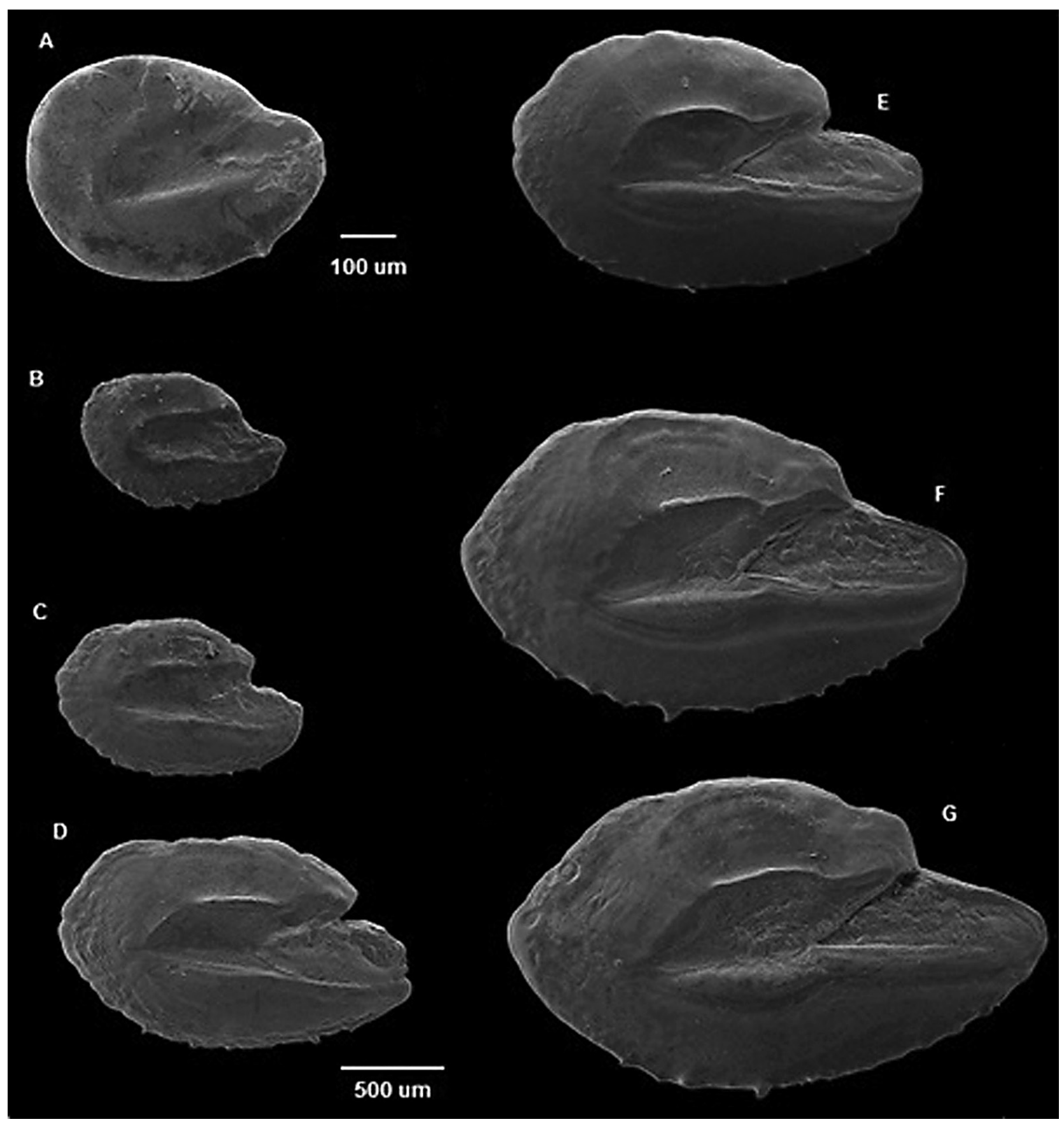

Fig. 3. - Micrographs of the inner face of the left sagitta otolith of Anchoa tricolor, with sizes of $22 \mathrm{~mm}(\mathrm{~A}), 34 \mathrm{~mm}(\mathrm{~B}), 40 \mathrm{~mm}(\mathrm{C}), 55 \mathrm{~mm}$ (D), $65 \mathrm{~mm}(\mathrm{E}), 75 \mathrm{~mm}(\mathrm{~F})$ and $81 \mathrm{~mm}(\mathrm{G})$. Images A (120x; scale $100 \mu \mathrm{m})$ and B-G (45×; scale $500 \mu \mathrm{m})$.

antirostrum and post-rostrum, respectively (Fig. 2). The remaining points selected, five dorsal and five ventral, were semi-landmarks $(2,4,5,6,7,9,10,11,12,13)$ (Fig. 2 ). An equidistant distance was maintained between the semi-landmarks, assisting in the interpretation of the otolith outline (Monteiro et al. 2005, Ponton 2006, Vignon and Morat 2010).

Landmarks and semi-landmarks were inserted in each photograph using the tpsUtil and tpsDig2 software. In the tpsRelw software, 3 landmarks and 10 semi-landmarks were assigned and fitted using the sliding method for semi-landmarks (Rohlf and Marcus 1993). The images were saved in TPS format in
TpsUtil and in TpsRelw we extracted the centroid size and plotted data in relative warps to identify possible variations in shape (Monteiro and Reis 1999, Ponton 2006). The relationship between the centroid size (otolith shape) and the fish length (TL) were checked using a linear regression. Subsequently, multivariate analysis of variance (MANOVA with Hotelling for significant test) was applied to test the difference between otolith shape and size class intervals in the Rmorph package, a geometric and multivariate morphometrics library for R (Baylac 2008). All analyses were performed in spreadsheet software and in PAST 3.06. In all statistical procedures $\alpha=0.05$. 

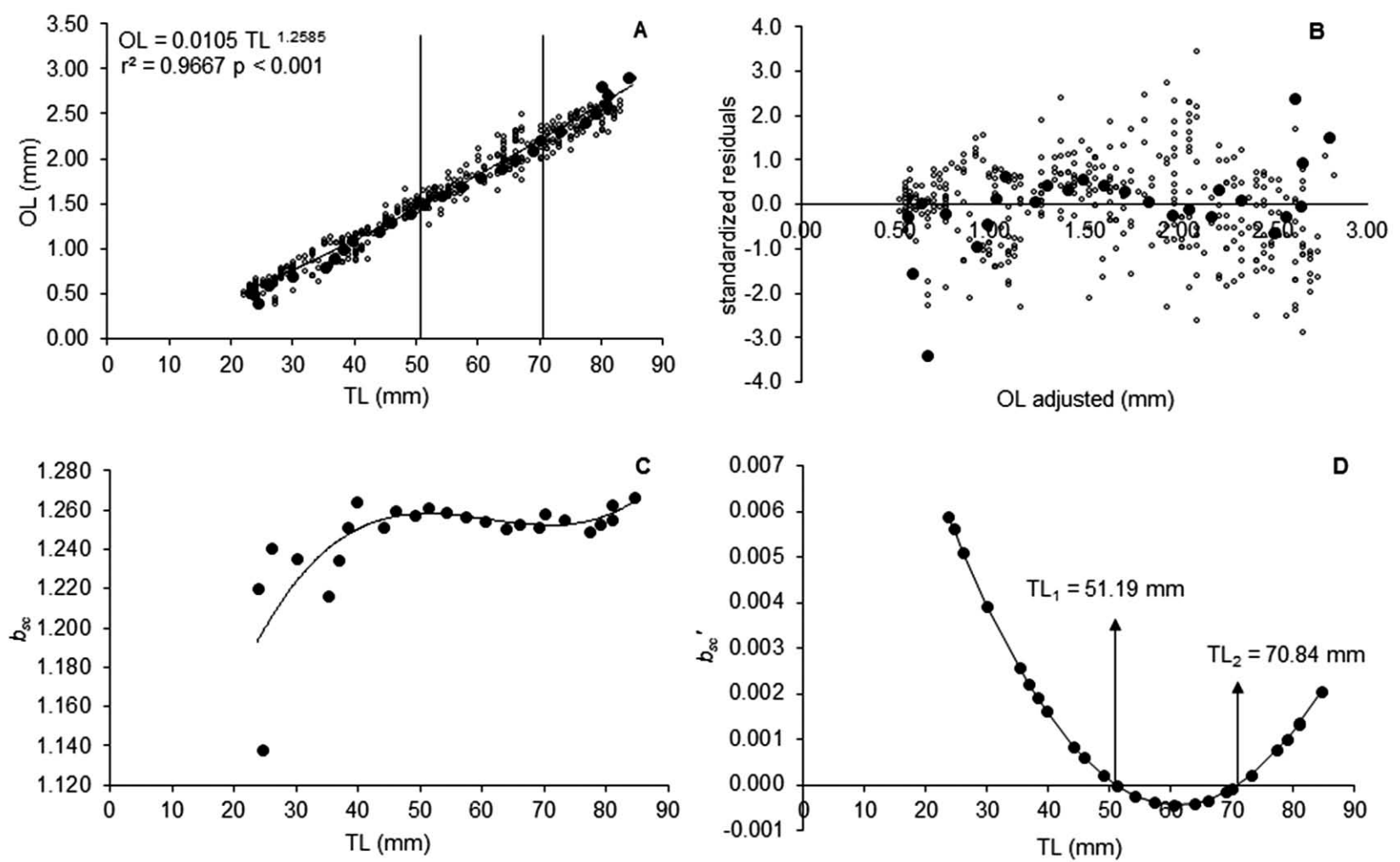

Fig. 4. - A, power regression between total length (TL) and otolith length (OL) of Anchoa tricolor of the Paranaguá Estuarine Complex (Paraná State, Brazil) (open circle = individual measurements; filled circle = average values for 0.1 mm OL class. B, standardized residuals adjusted from power regression. $\mathrm{C}$, exponential coefficient $\left(b_{s c}\right)$ for each total length (line $=$ polynomial function). $\mathrm{D}$, first derivative of polynomial function showing the stanza changing points of total length $\left(\mathrm{TL}_{1}\right.$ and $\left.\mathrm{TL}_{2}\right)$.

\section{RESULTS}

A total of 397 specimens of A. tricolor (TL range: 22 to $85 \mathrm{~mm}$; TW range: 0.04 to $3.76 \mathrm{~g}$ ) were analysed. The general morphological pattern of otolith was the following: elliptic shape; round anterior-posterior region; margins varying between serrated (ventral) and smooth (dorsal) over ontogenetic development; heterosulcoid and ostial sulcus acusticus, deep and located in the middle region of the otolith; well-developed rostrum, antirostrum, rostrum and antirostrum in agreement, excisural notch shallow and acute in the otolith (Fig. 3). Some morphological attributes varied during the ontogenetic development. In smaller fish (21-25 mm TL), shape was circular (Fig. 3A). In fish of 35-45 $\mathrm{mm} \mathrm{TL}$, the excisura intensified and was maintained (Fig. 3D). At 55-75 mm TL, the dorsal margin of the otolith started to crenate and at 75-85 $\mathrm{mm}$ TL it reached the general pattern.

The regressions involving otolith length were $\mathrm{OL}=0.0105 \mathrm{TL}^{1.2585}\left(\mathrm{r}^{2}=0.9667, \mathrm{p}<0.001\right)($ Fig. 4A) and $\mathrm{OL}=1.6862 \mathrm{TW}^{0.3732}\left(\mathrm{r}^{2}=0.9669, \mathrm{p}<0.001\right)$ (Fig. 5A). The residual analysis evidenced more than one growth phase (Fig. 4B and 5B). The polynomial equations fitted were $b_{s c}=1.515 \times 10^{-6} \mathrm{TL}^{3}-2.773 \times 10^{-4} \mathrm{TL}^{2}+$ $0.01648 \mathrm{TL}+0.938$ (Fig. 4C) and $b_{s c}=-0.02011 \mathrm{TW}^{3}$ $+0.1534 \mathrm{TW}^{2}-0.3145 \mathrm{TL}+0.4734$ (Fig. 5C). The first derivatives from these equations were used to detect the stanza changing points. Three growth phases (two stanza changing points) were identified, related to 51.19 and $70.84 \mathrm{~mm}$ TL (Fig. 4D) and to 1.42 and
$3.66 \mathrm{~g}$ (Fig. 5D), respectively. These TWs correspond to $67.6 \mathrm{~mm}$ and $89.6 \mathrm{~mm}$ TL. In relation to the relative sulcus surface index, its maximum development occured in the main phase of longitudinal otolith development, corresponding to the second growth phase (41-60 mm TL) of A. tricolor.

Shape indices of $A$. tricolor otoliths showed different patterns of variation (Table 1): the aspect ratios, relative sulcus surface index and rostrum index were positive related to the TL, but the rectangularity and the roundness showed a negative pattern. After size effect removal, the shape indices also showed tendencies related to TL, both in the separate analysis of each index (Fig. 7) and in the joint analysis (PERMANOVA pseudo-F $=13.6, p<0.001$ ) (see Table 2 for the results of pairwise comparisons). Joining these results and also taking into consideration the otolith morphology (Fig. 3), at least three distinct growth phases of $A$. tricolor were identified, as follows. The first growth phase was related to individuals of less than $40 \mathrm{~mm}$ $\mathrm{TL}$, in which the distinct pattern of shape indices reflected the conspicuous morphological changes in the otolith. In this phase, the body growth was greater than the otolith growth in length (lower values of the OL/ TL aspect ratio), although otoliths showed a reduction in their circularity. This was revealed by decreasing values of $\mathrm{OH} / \mathrm{OL}$ and roundness and a gradual increase in the rectangularity and rostrum index (Fig. 6). The second growth phase clearly occurred between 41 and $60 \mathrm{~mm}$ TL, although in some indices up to $70 \mathrm{~mm}$ TL. Due to the pronounced growth in the longitudinal axis, 

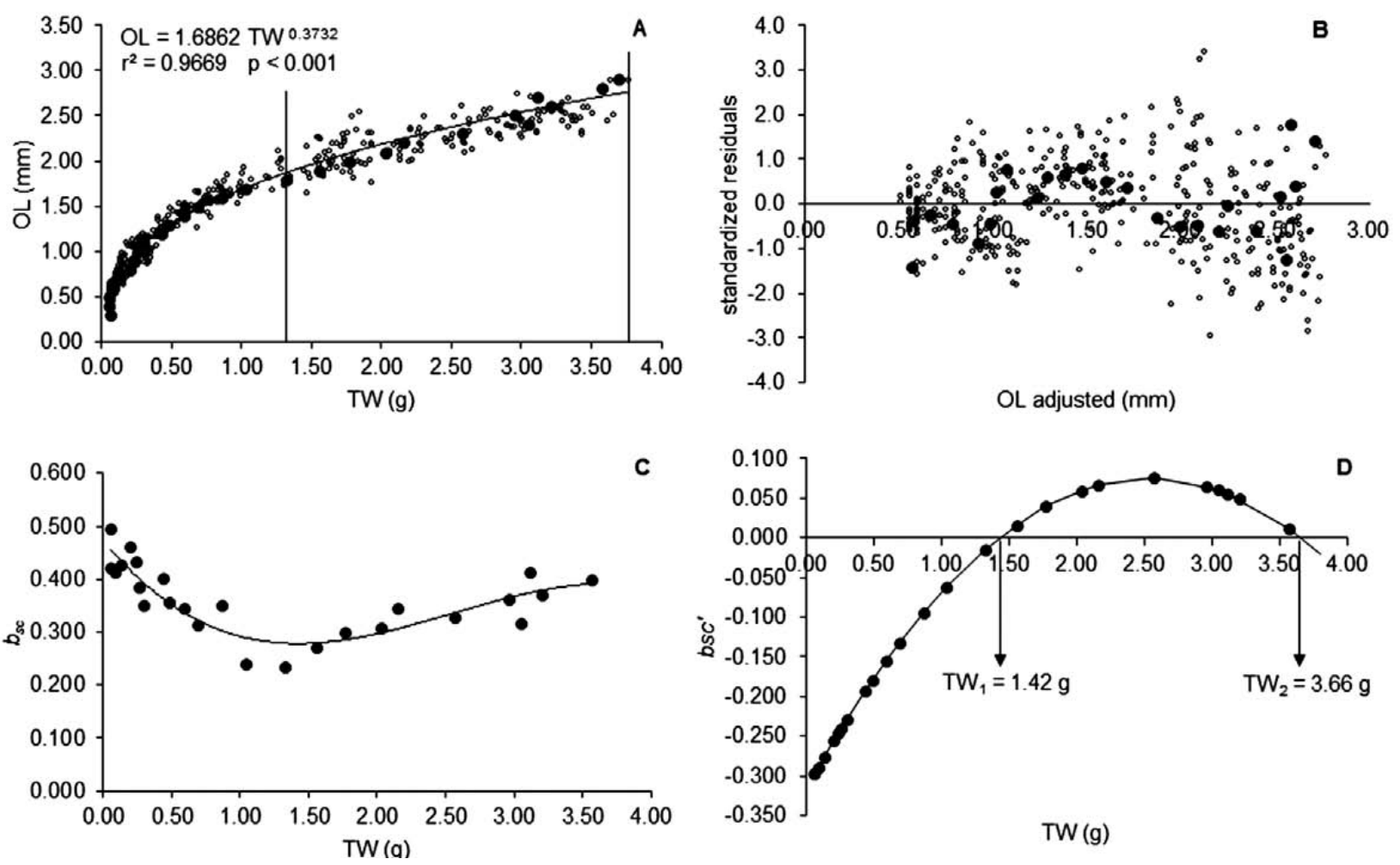

Fig. 5. - A, power regression between total weight (TW) and otolith length (OL) of Anchoa tricolor of the Paranaguá Estuarine Complex (Paraná State, Brazil) (open circle $=$ individual measurements; filled circle $=$ average values for $0.1 \mathrm{~mm}$ OL class. B, standardized residuals adjusted from power regression. $\mathrm{C}$, exponential coefficient $\left(b_{s c}\right)$ for each total weight (line $=$ polynomial function). D, first derivativee of polynomial function showing the stanza changing points of total weight $\left(\mathrm{TW}_{1}\right.$ and $\left.\mathrm{TW}_{2}\right)$.

the rectangular shape of otoliths became evident (highest values of OL/TL aspect ratio and rectangularity and lowest values of $\mathrm{OH} / \mathrm{OL}$ aspect ratio and roundness). In this phase, the rostrum reached its maximum proportional development (highest values of rostrum index) (Fig. 6). From 61 to $71 \mathrm{~mm}$ TL, otoliths remained constant in their patterns. Aspects ratios indicated an $\mathrm{OL}$ and $\mathrm{OH}$ with proportionally low rectangularity and more circularity (high roundness). The rostrum index also remained constant (Fig. 6).

The scatterplot of relative warps illustrated a set of dots arranged closer to RW1, which showed more elongated otoliths, different from the group closer to RW2, which was more associated with more rounded otoliths (Fig. 7). Based on the total length and the centroid size, regression analyses were run (TL:Centroid Size: $\left.\mathrm{y}=-3.11 \times 10^{15}+1.30 \times 10^{15} \mathrm{x} ; \mathrm{r}^{2}=0.9707, \mathrm{p}<0.001\right)$. Moreover, for all Cartesian coordinates, the MANOVA revealed significant differences between all size classes (Wilk's $\lambda=0.002$; $F=24.44$, $p<0.001$ ). A comparison between the centroid size and class intervals by MANOVA showed significant differences in the interaction of all class intervals $(\mathrm{p}<0.001)$, except for the interaction between 71-80 $\mathrm{mm}$ and 81-90 ( $\mathrm{p}=0.089)$.

\section{DISCUSSION}

In the present study, the objectives were achieved and concise morphologic and morphometric descriptions of $A$. tricolor otolith have been presented. Although the identification of smaller specimens from otoliths is more difficult, due to their unfinished de-
Table 1. - Huxley model (power regressions, $\mathrm{y}=a \mathrm{x}^{b}$ ) between total length (TL) and shape indices (see the text for details) of Anchoa tricolor in the Paranaguá Estuarine Complex (Paraná State, Brazil) $\left(n=64 ; r^{2}\right.$, coefficient of determination; $p$, probability value).

\begin{tabular}{lcccc}
\hline \multicolumn{1}{c}{ x vs. $y$} & $a$ & $b$ & $\mathrm{r}^{2}$ & $\mathrm{p}$ \\
\hline TL vs. OL/TL & 0.0113 & 0.242 & 0.7683 & $2.36 \times 10^{-21}$ \\
TL vs. OH/OL & 1.6125 & 0.219 & 0.8195 & $9.95 \times 10^{-25}$ \\
TL vs. Rectangularity & 0.8475 & -0.036 & 0.4429 & $1.97 \times 10^{-9}$ \\
TL vs. Roundness & 1.7437 & -0.255 & 0.8721 & $2.23 \times 10^{-29}$ \\
TL vs. Relative sulcus surface & 0.2168 & 0.069 & 0.1417 & 0.00217 \\
TL vs. Rostrum index & 0.1229 & 0.169 & 0.3694 & $1.00 \times 10^{-7}$ \\
\hline
\end{tabular}

Table 2. - Probability values (p) obtained from a post-hoc MannWhitney test (with Bonferroni correction) in order to detect differences in shape indices related to total length (TL) class $(\mathrm{mm})$ of Anchoa tricolor in the Paranaguá Estuarine Complex (Paraná State, Brazil) (bold italics emphasize significant differences, $\mathrm{p}<0.05$ ).

\begin{tabular}{ccccccc}
\hline TL class $(\mathrm{mm})$ & $21-30$ & $31-40$ & $41-50$ & $51-60$ & $61-70$ & $71-80$ \\
\hline $31-40$ & $\mathbf{0 . 0 3 2}$ & & & & & \\
$41-50$ & $\mathbf{0 . 0 0 2}$ & $\mathbf{0 . 0 0 4}$ & & & & \\
$51-60$ & $\mathbf{0 . 0 0 2}$ & $\mathbf{0 . 0 0 2}$ & 1.000 & & & \\
$61-70$ & $\mathbf{0 . 0 0 4}$ & 0.139 & $\mathbf{0 . 0 0 2}$ & $\mathbf{0 . 0 0 2}$ & & \\
$71-80$ & 0.063 & 0.056 & $\mathbf{0 . 0 0 2}$ & $\mathbf{0 . 0 0 2}$ & $\mathbf{0 . 0 0 2}$ & \\
$81-90$ & 1.000 & 1.000 & $\mathbf{0 . 0 0 2}$ & $\mathbf{0 . 0 0 2}$ & $\mathbf{0 . 0 0 2}$ & 1.000 \\
\hline
\end{tabular}

velopment, in larger (and/or adult) specimens otolith features differentiate among genera of the same family, allowing them to be differentiated (Campana 2001, Ponton 2006, Tuset et al. 2008).

Sagitta otolith morphology has been described for diverse species of engraulids (Smale et al. 1995) and for A. tricolor there was a previous description (Lemos et al. 1995). The limitations due to the methodologies 

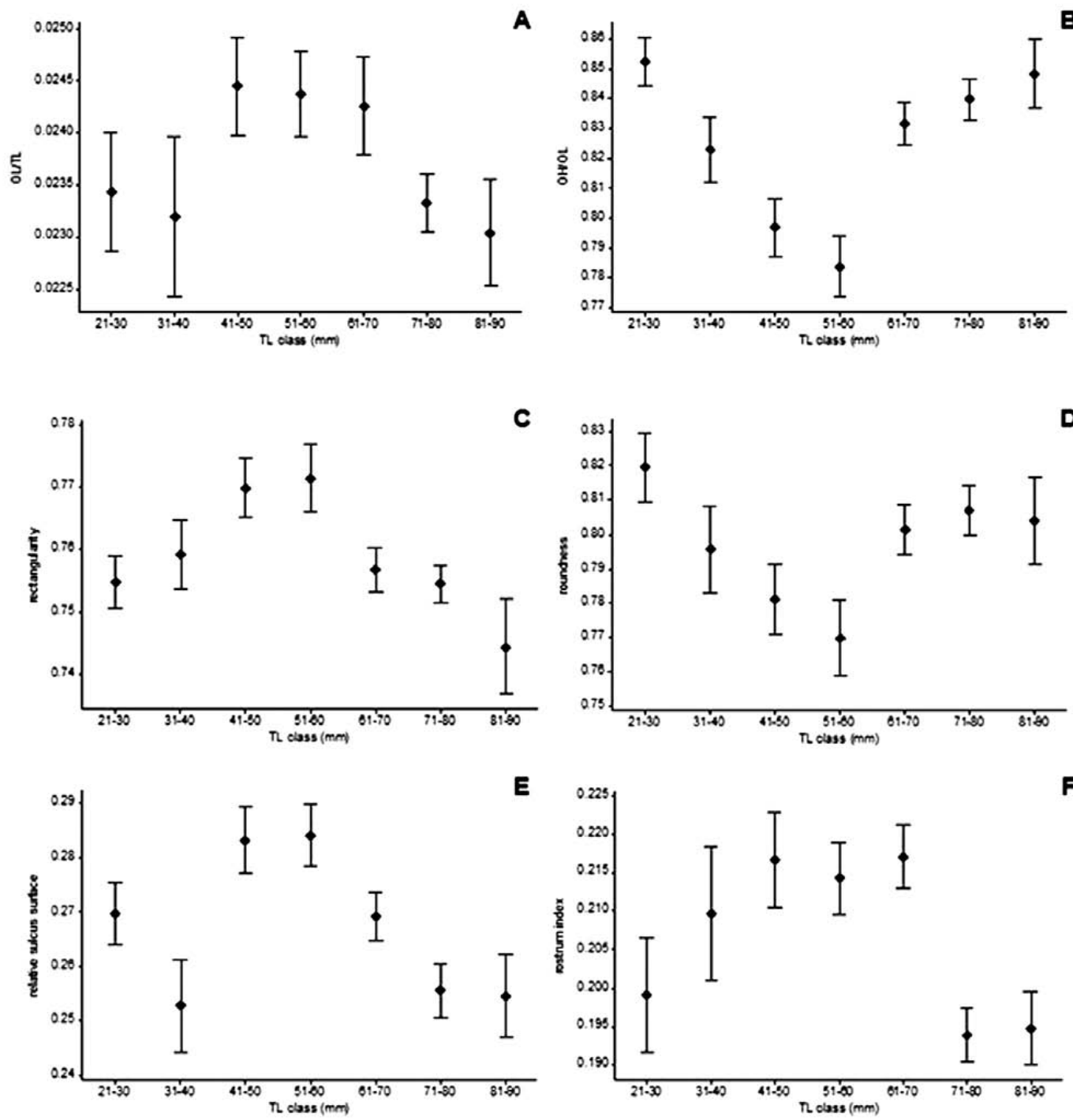

Fig. 6. - Mean and confidence interval (95\%) of the otolith shape indices of Anchoa tricolor by total length (TL) class in the Paranaguá Estuarine Complex (Paraná State, Brazil). A, aspect ratio of the otolith length (OL) and total length (TL). B, aspect ratio of the otolith height $(\mathrm{OH})$ and length $(\mathrm{OL}) . \mathrm{C}$, rectangularity index. D, roundness index. E, relative sulcus acusticus surface index. F, rostrum index.



Fig. 7. - Thin-plate splines are represented near the position of the groups on the relative warps 1-2 ordination plot of the otolith shape of Anchoa tricolor. 
and technologies of that time restricted comparisons and the current use of these earlier results (Lemos et al. 1995), but it was possible to identify some characteristics of the sagitta of anchovies from other studies. The most common characteristics among the species of engraulids are small to medium otolith, heterosulcoid and ostial sulcus acusticus. In A. tricolor, the otoliths have an elliptic shape, whereas in Thryssa sitirostris, Thryssa vitrirostris and Engraulis japonicas it is oval, elliptic and fusiform (Smale et al. 1995). In Engraulis australis, the shape varies from oval to fusiform (Furlani et al. 2007), being elliptic in Engraulis encrasicolus (Tuset et al. 2008). As is well known, otolith patterns vary in accordance with genera. What, then, is the utility of the description presented in the current study? Although it is not possible to identify the other congeneric species, in the study area A. tricolor is the most abundant and important engraulid in the PEC (Contente et al. 2011) and other coastal areas, including the inner continental shelf $(<50 \mathrm{~m}$ depth) (RossiWongtschowski et al. 2014). This fact per se highlights the importance of an otolith description of this species, even disregarding other congenerics.

Morphological and morphometric evidences indicate that the sagitta otolith represent three ontogenetic development stages of $A$. tricolor. Although no perfect coincidence was found in terms of TL values among the analyses performed (nor was it expected), it was possible to associate these stages with the biology of the species and habitat (Vignon and Morat 2010, Avigliano and Volpedo 2013).

The specimens of $A$. tricolor up to $40 \mathrm{~mm} \mathrm{TL}$ perform short displacements, given the incomplete development of the dorsal and anal fins (Hofstaetter et al. 2004). The species inhabits the estuary at this stage (Araújo et al. 2008) and still has more rounded otoliths with a small rostrum, which corresponds to fish with low swimming ability (Volpedo and Echeverría 2003, Volpedo et al. 2008). The circular shape is inherited from the larval phase (Joh et al. 2015), which will be progressively reduced. From 41 to $60-70 \mathrm{~mm}$ TL, the swimming capacity of the anchovy increases, enabling its migration out of the estuary. This characteristic is reflected in the morphology and morphometry of the otoliths, with greater development of the excisura and higher growth of the rostrum. In this second growth phase, most of the morphological attributes are attained. Also during this stage, the species moves up to the inner continental shelf (Araújo et al. 2008), where it forms large shoals (Rossi-Wongtschowski et al. 2014). The third growth phase is related to the first maturation in the anchovy, close to 61-70 $\mathrm{mm}$ TL, both quoted in Whitehead et al. (1988) and diagnosed from analysis of the current data, still unpublished. The morphological and morphometric patterns of adults are achieved, when the otolith finally can be characterized as an $A$. tricolor otolith. Nevertheless, the descriptions presented for the earlier phases are useful, considering the morphological differences of other species and genera (Lemos et al. 1995).

The identification of these three growth phases of A. tricolor, the first two related to juveniles and the third one to adults, gains support in view of the holistic approach adopted here, i.e. the use of different and independent methodologies that converge to the same result. The only result that partially disagreed with the general pattern was the regression between OL and total weight of the fish (TW vs. OL). TW of fish is influenced on different temporal scales by feeding (Zavala-Camin 1996) and particularly by reproduction (Froese 2006). In the anchovy, the first maturation created a conspicuous stanza changing point (the first) in the TW-OL relationship; the second one was so close to the end of the regression that it must be disregarded.

Despite the subjectivity of morphological evaluations (Rondon et al. 2014), the morphometry is quantitative and tends to be more accurate (Monteiro and Reis 1999). Traditional morphometry (the Huxley model) has a broad use related to fish studies (Casselman 1990, Hunt 1992, Volpedo and Echeverría 1997). Bervian et al. (2006) brought to it an important new approach, using the size effect as a tool for detecting changes related to different growth phases. This tool cannot always be functional: if the residual analysis follows their assumptions (Zar 2010), then this technique will be inappropriate (Bervian et al. 2006).

The initial use of geometric morphometrics applied to ontogeny was controversial (Rohlf 1998, Zelditch et al. 1998). In the early 2000 s, the emergence of the geometric morphometrics applied to fishes brought a new precise and accurate tool to bioecology, fisheries research and related areas (Loy et al. 1998, 2000, Torres et al. 2000). Ponton (2006) stated its use in otolithology and its reference has quickly become a classical citation.

In the case of $A$. tricolor, geometric morphometrics showed clear patterns of change of shape during ontogenetic development, which would be related to the polyphase growth for the species found in this study. As with Anchoa tricolor, geometric morphometry was also efficient in the description of ontogenetic development of otoliths of Clupeiformes (Ponton 2006, Libungan et al. 2015). The lack of significance between the two major class intervals shown by geometric morphometrics indicates that there is a stability in the shape of the anchovy otoliths after first maturity.

The morphological and morphometric characterization of the sagitta of $A$. tricolor, more than another descriptive study about otoliths, reflected most of its life cycle inside an estuary. There are few references focusing on this kind of analysis (Hare and Cowen 1994, Hüssy 2008, Vignon 2012), but the use adopted here proved to be useful and efficient. Considering that A. tricolor is an important species both in coastal areas and on the inner continental shelf of the southwestern Atlantic, the present results are valuable.

\section{ACKNOWLEDGEMENTS}

The authors are grateful for funding from the project CAFP-BA/SPU. They also thank CONICET and UBACYT, CAPES for the master's degree scholarship to the first author, LAFMA(CEM-UFPR) for the stereomicroscope and the Olympus DP71 camera, and the 
Centro de Microscopia Eletrônica (UFPR) for the micrographs. The editors and anonymous reviewers are thanked for constructive comments which improved our manuscript.

\section{REFERENCES}

Anderson M.J., Gorley R.N., Clarke K.R. 2008. PERMANOVA+ for PRIMER: guide to software and statistical methods. PRIMER-E, Plymouth.

Araújo F.G., Silva M.A., Azevedo M.C.C., et al. 2008. Spawning season, recruitment and early life distribution of Anchoa tricolor (Spix and Agassiz, 1829) in a tropical bay in southeastern Brazil. Braz. J. Biol. 684: 823-829. http://dx.doi.org/10.1590/S1519-69842008000400018

Assis C.A. 2005. The utricular otoliths, lapilli, of teleosts: their morphology and relevance for species identification and systematics studies. Sci. Mar. 69: 259-273. http://dx.doi.org/10.3989/scimar.2005.69n2259

Avigliano E., Volpedo A.V. 2013. Use of otolith strontium: calcium ratio as indicator of seasonal displacements of the silverside (Odontesthes bonariensis) in a freshwater-marine environment. Mar. Freshwater. Res. 64: 1-6. http://dx.doi.org/10.1071/MF12165

Avigliano E., Martinez-Riaños F., Volpedo A.V. 2014. Combined use of otolith microchemistry and morphometry as indicators of the habitat of the silverside (Odontesthes bonariensis) in a freshwater-estuarine environment. Fish. Res. 149: 55-60. http://dx.doi.org/10.1016/j.fishres.2013.09.013

Baylac M. 2008. Rmorph: a R geometric and multivariate morphometrics library. Available from the author: baylac@mnhn.fr

Bellido J.M., Pierce G.J., Romero J.L., et al. 2000. Use of frequency analysis methods to estimate growth of anchovy (Engraulis encrasicolus L. 1758) in the Gulf of Cadiz (SW Spain). Fish. Res.48: 107-115. http://dx.doi.org/10.1016/S0165-7836(00)00183-1

Bervian G., Fontoura N.F., Haimovici M. 2006. Statistical model of variable allometric growth: otolith growth in Micropogonias furnieri (Actinopterygii, Sciaenidae). J. Fish. Biol. 68: 196-208. http://dx.doi.org/10.1111/j.0022-1112.2006.00890.x

Bornatowski H., Braga R.R., Abilhôa V., et al. 2014. Feeding ecology and trophic comparisons of six shark species in a coastal ecosystem off southern Brazil. J. Fish. Biol. 85: 246-263. http://dx.doi.org/10.1111/jfb.12417

Bugoni L., Vooren C.M. 2004. Feeding ecology of the Common tern Sterna hirundo in a wintering area in southern Brazil. Ibis.146: 438-453. http://dx.doi.org/10.1111/i.1474-919X.2004.00277.x

Cadrin S.X., Friedland K.D. 1999. The utility of image processing techniques for morphometric analysis and stock identication. Fish. Res. 43:129-139. http://dx.doi.org/10.1016/S0165-7836(99)00070-3

Campana S.E. 2001. Accuracy, precision and quality control in age determination, including a review of the use and abuse of age validation methods. J. Fish. Biol. 59: 197-242. http://dx.doi.org/10.1111/j.1095-8649.2001.tb00127.x

Campana S.E., Casselman J.M. 1993. Stock discrimination using otolith shape analysis. Can. J. Fish. Aquat. Sci. 50: 1-22. http://dx.doi.org/10.1139/f93-123.

Carvalho F.M., Castello J.P. 2013. Argentine anchovy (Engraulis anchoita) stock identification and incipient exploitation in southern Brazil. Lat. Am. J. Aquat. Res. 41: 820-827. http://dx.doi.org/10.3856/vol41-issue5-fulltext-2

Carvalho B.M., Corrêa M.F.M. 2014. Morphometry of the sagitta otolith from Atherinella brasiliensis (Quoy and Gaimard, 1824) (Actinopterygii - Atherinopsidae), at the coast of Paraná. Rev. Trop. Oceanogr. 42: 54-59.

Casselman J.M. 1990. Growth and relative size of calcified structures of fish. T. Am. Fish. Soc., 119(4): 673-688. http://dx.doi.org/10.1577/1548-8659(1990)119<0673:GARSO $\mathrm{C}>2.3 . \mathrm{CO} ; 2$

Contente R.F., Stefanoni M.F., Spach H. L. 2011. Fish assemblage structure in an estuary of the Atlantic Forest biodiversity hotspot (southern Brazil). Ichthyol Res. 58: 38-50 http://dx.doi.org/10.1007/s10228-010-0192-0

De La Cruz-Agüero J., García-Rodríguez F. J., De La Cruz-Agüero G., et al. 2012. Identification of gerreid species (Actinopterygii: Perciformes: Gerreidae) from the pacific coast of Mexico based on sagitta otolith morphology analysis. Acta Ichthyol. Piscat. 42(4): 297-306.

http://dx.doi.org/10.3750/AIP2012.42.4.03

Elsdon T.S., Wells B.K., Campana S.E., et al. 2008. Otolith chemistry to describe movements and life-history parameters of fishes: hypotheses, assumptions, limitations and inferences. Oceanogr. Mar. Biol. Ann. Rev. 46: 297-330. http://dx.doi.org/10.1201/9781420065756.ch7

Franco T.P., Araújo C.E.O., Araújo F.G. 2013. Length-weight relationships for 25 fish species from three coastal lagoons in Southeastern Brazil. J. Appl. Ichthyol. 30(1): 248-250. http://dx.doi.org/10.1111/jai.12271

Froese R. 2006. Cube law, condition factor and weight-length relationships: history, meta-analysis and recommendations. J. App. Ichthyol. 22(4): 241-253. http://dx.doi.org/10.1111/j.1439-0426.2006.00805.x

Furlani D., Gales R., Pemberton D. 2007. Otoliths of common Australian temperate fish: a photographic guide. Collingwood: CSIRO Publishing, $32 \mathrm{pp}$.

Gonzalez-Naya M.J., Tombari A., Volpedo A.V., et al. 2012. Size related changes in sagitta otoliths of Australoheros facetus (Pisces; Cichlidae) from South America. J. Appl. Ichthyol. 28: $752-755$ http://dx.doi.org/10.1111/j.1439-0426.2012.02006.x

Hare J.A., Cowen R.K. 1994. Ontogeny and otolith microstructure of bluefish Pomatomus saltatrix (Pisces: Pomatomidae). Mar. Biol. 118(4): 541-550. http://dx.doi.org/10.1007/BF00347500

Hofstaetter M., Godefroid R.S., Sobolewski M., et al. 2004. Estágios iniciais do ciclo de vida de Anchoa tricolor (Agassiz, 1829) (Teleostei: Engraulidae). Rev. Uniandrade. 5: 81-94.

Hunt J.J. 1992. Morphological characteristics of otoliths for selected fish in the Northwest Atlantic. J. Northwest Atl. Fish. Sci. 13: 63-75. http://dx.doi.org/10.2960/J.v13.a5

Huxley J.S. 1993. Problems of relative growth; with a new introduction. Baltimore, The John Hopkins University Press.

Hüssy K. 2008. Otolith shape in juvenile cod (Gadus morhua): Ontogenetic and environmental effects. J. Exp. Mar. Biol. Ecol. 364(1): 35-41. http://dx.doi.org/10.1016/j.jembe.2008.06.026

IUCN. 2014. http://www.iucnredlist.org/

Joh M., Matsuda T., Miyazono, A. 2015. Common otolith microstructure related to key early life-history events in flatfishes identified in the larvae and juveniles of cresthead flounder Pseudopleuronectes schrenki. J. Fish Biol. 86: 448-462. http://dx.doi.org/10.1111/jfb.12562

Lana P.C., Marone E., Lopes R.M., et al. 2001. The Subtropical Estuarine Complex of Paranaguá Bay, Brazil. In: Seeliger U. Kjerfve B. (eds), Coastal Marine Ecosystems of Latin America, Series Ecological Studies 144: 131-145. Berlin, Springer-Verlag. http://dx.doi.org/10.1007/978-3-662-04482-7_11

Lemos P.H.B., Corrêa M.F.M., Pinheiro P.C. 1995. Catálogo de otólitos de Engraulidae (Clupeiformes-Osteichthyes) do litoral do Estado do Paraná, Brasil. Braz. Arch. Biol. Tech. 38(3): 731-745.

Leguá J., Plaza G., Pérez D., et al. 2013. Otolith shape analysis as a tool for stock identification of the southern blue whiting, Micromesistius australis. Lat. Am. J. Aquat. Res. 41: 479-489.

Libungan L.A., Oskarsson G.J. Slotte A., et al. 2015. Otolith shape: a population marker for Atlantic herring Clupea harengus. J. Fish. Biol. 86: 1377-1395. http://dx.doi.org/10.1111/jfb.12647

Lombarte A. 1992. Changes in otolith area: sensory area ratio with body size and depth. Environ. Biol. Fish. 33: 405-410. http://dx.doi.org/10.1007/BF00010955

Lombarte A., Lleonart J. 1993. Otolith size changes related with body grotwh, habitat depth and temperature. Environ. Biol. Fish. 37: 297-306 http://dx.doi.org/10.1007/BF00004637

Loy A., Mariani L., Bertelletti M., et al. 1998. Visualizing allometry: geometric morphometrics in the study of shape changes in the early stages of the two-banded sea bream, Diplodus vulgaris (Perciformes, Sparidae). J. Morphol. 237(2): 137-146. h t t p : / / d x . d o i . o r g / $10 \% 1002 /$ (sici) 1097-4687(199808)237:2<137::aid-jmor5>3.0.co;2-z

Loy A., Boglione C., Gagliardi F., et al. 2000. Geometric morphometrics and internal anatomy in sea bass shape analysis (Dicentrarchus labrax L., Moronidae). Aquac. 186: 33-44. http://dx.doi.org/10.1016/S0044-8486(99)00366-X 
Monteiro L.R., Reis S.F. 1999. Princípios de morfometria geométrica. Ribeirão Preto, Editora Holos, 198 pp.

Monteiro L.R., Di Beneditto A.P.M., Guillermo L.H., et al. 2005. Allometric changes and shape differentiation of sagitta otoliths in sciaenid fishes. Fish. Res. 74: 288-299. http://dx.doi.org/10.1016/j.fishres.2005.03.002

Nolf D. 1985. Otolith piscium. In: Schultze H.P. (ed.). Handbook of Paleoichthyology, Vol. X, Stuttgart and New York, Fisher, pp. $1-145$.

Passos A.C., Contente R.F., Araújo C.C.V., et al. 2012. Fishes of Paranaguá Estuarine Complex, South West Atlantic. Biota Neotrop. 12: 227-241 http://dx.doi.org/10.1590/S1676-06032012000300022

Perin S., Vaz-dos-Santos A.M. 2014. Morphometry and relative growth of the Brazilian sardine, Sardinella brasiliensis (Steindachner, 1879) in the Southeastern Brazilian Bight. Arq. Zool. 45: $63-72$ http://dx.doi.org/10.11606/issn.2176-7793.v45iespp63-72

Ponton D. 2006. Is geometric morphometrics efficient for comparing otolith shape of different fish species? J. Morphol. 267: 750-757. http://dx.doi.org/10.1002/jmor.10439

Popper A.N., Ramcharitar J., Campana S.E. 2005. Why otoliths? Insights from inner ear physiology and fisheries biology. Mar. Freshwater. Res. 56: 497-504. http://dx.doi.org/10.1071/MF04267

Rohlf F.J. 1998. On applications of geometric morphometrics to studies of ontogeny and phylogeny. Syst. Biol. 47(1): 147-158. http://dx.doi.org/10.1080/106351598261094

Rohlf F.J., Marcus L.F. 1993. A revolution in morphometrics. Trends. Ecol. Evol. 8: 129-132. http://dx.doi.org/10.1016/0169-5347(93)90024-J

Rondon A.S., Vaz-dos-Santos A.M., Rossi-Wongtschowski C.L.D.B. 2014. Morfologia e biometria dos otólitos de Beryx splendens e Hoplostethus occidentalis (Beryciformes) no Atlântico Sudoeste. Bol. Inst. Pesca. 40(2): 195-206.

Rossi-Wongtschowski C.L.B., Vaz-dos-Santos A.M., Siliprandi C.C. 2014. Checklist of the marine fishes collected during hydroacoustic surveys in the Southeastern Brazilian Bight from 1995 to 2010. Arq. Zool. 45: 73-88. http://dx.doi.org/10.11606/issn.2176-7793.v45iespp73-88

Santos M.C.O., Rosso S., Santos R.A., et al. 2002. Insights on small cetacean feeding habits in southeastern Brazil. Aquat. Mam. 28: 38-45.

Smale J.M., Watson G., Hecht T. 1995. Otolith atlas of southern African marine fishes. J.L.B Smith Institute of Ichthyology, 74 pp.

Tombari A., Volpedo A.V., Echeverría D.D. 2005. Desarrollo de la sagitta en juveniles y adultos de Odontesthes argentiniensis (Valenciennes, 1835) y O. bonariensis (Valenciennes, 1835) de la provincia de Buenos Aires, Argentina (Teleostei: Atheriniformes). Rev. Chil. Hist. Nat. 78: 623-633. http://dx.doi.org/10.4067/S0716-078X2005000400003

Torres G.J., Lombarte A., Morales-Nin B. 2000. Variability of the sulcus acusticus in the sagittal otolith of the genus Merluccius (Merlucciidae). Fish. Res. 46(1-3): 5-13. http://dx.doi.org/10.1016/S0165-7836(00)00128-4

Tuset V.M., Lozano I.J., Gonzalez J.A., et al. 2003a. Shape indices to identify regional differences in otolith morphology of comber, Serranus cabrilla (L., 1758). J. Appl. Ichthyol. 19: 88-93. http://dx.doi.org/10.1046/j.1439-0426.2003.00344.x

Tuset V.M., Lombarte A., González J.A., et al. 2003b. Comparative morphology of the sagitta otolith. J. Fish. Biol. 63: 1491-1504. http://dx.doi.org/10.1111/j.1095-8649.2003.00262.x

Tuset V.M., Lombarte A., Assis C.A. 2008. Otolith atlas for the western Mediterranean, north and central eastern Atlantic. Sci. Mar. 72S1: 7-198.

http://dx.doi.org/10.3989/scimar.2008.72s 17

Tuset V.M., Azzurro E., Lombarte A. 2012. Identification of Lessepsian fish species using the sagitta otolith. Sci. Mar. 76(2): 289-299.

http://dx.doi.org/10.3989/scimar.03420.18E

Vaz-dos-Santos A.M., Rossi-Wongtschowski C.L.D.B. 2013. Length-weight relationships of the ichthyofauna associated with the Brazilian sardine, Sardinella brasiliensis, on the Southeastern Brazilian Bight $\left(22^{\circ} \mathrm{S}-29^{\circ} \mathrm{S}\right)$ between 2008 and 2010. Biota Neotrop. 13(2): 1-6. http://dx.doi.org/10.1590/S1676-06032013000200034

Vignon M. 2012. Ontogenetic trajectories of otolith shape during shift in habitat use: Interaction between otolith growth and environment. J. Exp. Mar. Biol. Ecol. 420: 26-32. http://dx.doi.org/10.1016/j.jembe.2012.03.021

Vignon M., Morat F. 2010. Environmental and genetic determinant of otolith shape revealed by a non-indigenous tropical fish. Mar. Ecol. Prog. Ser. 411: 231-241 http://dx.doi.org/10.3354/meps08651

Vilar C.C., Spach H.L., Joyeux J.C. 2011. Spatial and temporal changes in the fish assemblage of a subtropical estuary in Brazil: environmental effects. J. Mar. Biol. Assoc. U.K. 91(3): 635-648. http://dx.doi.org/10.1017/S0025315410001943

Volpedo A.V., Echeverría D.D. 1997. Morfología de las sagittae de lenguados del Mar Argentino (Bothidae, Paralichthydae y Achiropsettidae). Thalassas 13: 113-126.

Volpedo A.V., Echeverría D.D. 1999: Morfología de los otolitos sagittae de juveniles y adultos de Micropogonias furnieri (Desmarest, 1823) (Sciaenidae). Rev. Cienc. Mar Thalassas 15: 19-24.

Volpedo A.V., Echeverría D.D. 2003. Ecomorphological patterns of the sagitta in fish on the continental shelf off Argentine. Fish. Res. 60: 551-560. http://dx.doi.org/10.1016/S0165-7836(02)00170-4

Volpedo A.V., Tombari A.A., Echeverría D.D. 2008. Ecomorphological patterns in otoliths of Antarctic fish. Polar Biol. 31(5): 635-640. http://dx.doi.org/10.1007/s00300-007-0400-1

Waessle J.A., Lasta C.A., Favero M. 2003. Otolith morphology and body size relationships for juvenile Sciaenidae in the Río de la Plata estuary $\left(35-36^{\circ}\right.$ S). Sci. Mar. 67: 233-240.

Whitehead P.J.P., Nelson G.J., Wongratana T. 1988. FAO Species Catalogue. Vol. 7. Clupeoid fishes of the world (Suborder Clupeoidei). An annotated and illustrated catalogue of the herrings, sardines, pilchards, sprats, shads, anchovies and wolf-herrings. FAO Fish. Synop. 125(7/2): 305-579.

Wilcox D., Dove B., Mcdavid D., et al. 2002. Image Tools 3.0 for Windows. http://compdent.uthscsa.edu/dig/itdesc.html

Zavala-Camin L.A. 1996. Introdução aos estudos sobre alimentação natural em peixes (1st ed.). Maringá: EDUEM - Editora da Universidade Estadual de Maringá.

Zar J.H. 2010. Biostatistical Analysis. Fourth Edition. Prentice Hall. pp. 947.

Zelditch M.L., Fink W.L., Swiderski D.L., et al. 1998. On applications of geometric morphometrics to studies of ontogeny and phylogeny: a reply to Rohlf. Syst Biol. 47: 159-167.

Zelditch M.L, Swiderski D.L., Sheets D.H. 2004. A practical companion to geometric morphometrics for biologists: Running analyses in freely-available software. http://booksite.elsevier.com/9780123869036/content/Workbook.pdf 